JOURNAL OF EDUCATIONAL REVIEW AND RESEARCH

e-ISSN: 2597-9752 dan p-ISSN: 2597-9760

This work is licensed under

a Creative Commons Attribution-NonCommercial 4.0 International License.

\title{
Science Learning Model Based on Moral Value
}

\author{
Tahmid Sabri ${ }^{1}$, Fitria Arifiyanti ${ }^{2}$ \\ Universitas Tanjungpura ${ }^{1,2}$ \\ Email: tahmidsabripgsd@gmail.com ${ }^{1}$, arfiyantifitria91@gmail.com²
}

\begin{abstract}
Keywords :
Science, Learning Model,

Moral Value

ABSTRACT

Moral value is essential to be instilled in students through

learning in school. Therefore, it is necessary to study

model in which there is emphasis moral value during

learning, especially through science learning. Therefore,

this study aims to develop a model of science-based

science moral values in the hope of helping teachers to

instill moral values in students. This study uses literature

study method with reference sources in the form of books,

scientific journals, and websites related to the development

of science-based learning moral values.
\end{abstract}

\section{INTRODUCTION}

The learning model is a plan or a pattern used as a guide in planning a learning in class or learning in the form of tutorial and to determine a set of learning including curriculum, books, computer, telephone, media and other supporting facilities (Joyce, 1882: 4). Furthermore Soekamto et al (in Nurulwati, 2000: 10) suggests the purpose of the learning model is a conceptual framework that describes a systematic procedure in organizing learning experiences to achieve particular learning, in this case, is the Moral Values Development Model in Science Learning in schools, students is expected not only to get cognitive aspect only, but affective aspect is also very necessary in addition to getting psychomotor aspect and another aspect, or it could be affective aspect already submitted, but planned, and not terprogran in planning in Learning Implementation Plan (RPP). This is in line with what Eggen and Kauchak suggest that the science-based model of science-based learning can contribute and guide teachers who will teach science in school. Arend (1997: 7) states "The term teaching model refers to a particul ar approach to the instruction that includes its goals, syntax, environment, and management system". Model is a learning approach as a teacher strategy in teaching to gtmaximum learning outcomes, in which related to objectives, activities, methods, and sources, media, environment, evaluation and management system. These are as learning structures that include initial activities, core activities, and end-of-learning activities that end with evaluations.

Moral values are normative values, and become a reference as an essential life view, such as: the values of faith and devotion to God Almighty, noble morality, clean, caring environment, intellectuals which are moral, emotional, morality, ethics, aesthetics, creativity, entrepreneurship, independent, diligent, economic, social, harmonious, unity, peace, love, togetherness, democratic, and responsible as a nation child of moral, dignified, polite, friendly and noble personality. Overall these values contain aspects of moral value, that is good, skilled, science and technology, healthy physical and mental, socially 
conscious, and able to determine the purpose of life. Moral, morals or manners are manners, morals, good behavior in association, work and daily life.

Schools are a means of formal education, which functions in part to 1) personal development and personality formation, 2) cultural transmission, 3) social integration, and 4) innovation (Bachtiar Rifai, 2004). In this case, it is clear that the task of the school is to develop cognitive, affective and psychomotor aspects that can be pursued through the implementation of learning models of moral values in science learning in schools, kindergartens, elementary, junior and senior high schools, even to universities.

By considering the function of the school above, then there are at least 3 important reasons underlying the implementation of learning models of moral values in science learning in schools, which are among others: 1). The need for a good character to be an integral part of the human being that includes a strong mind, a heart and a qualified will, such as having honesty, empathy, attention, self-discipline, perseverance, and a strong moral drive to work with love as a hallmark maturity of human life; 2). Schools are a better place and more conducive to teaching and learning; 3 ). The learning of moral values is essential for developing qualified human resources (HR) and building a moral society (Lickona, 1996, P.1993). The students are part of the individual who must be educated and equipped with moral values through guidance and direction from other parties so that they will become qualified and reliable individuals (Suhartono, 2008), in this case in the teacher's school that plays a role so that hope can be achieved well.

Seeing the conditions in the field, teachers tend to prioritize the cognitive/cognitive aspect, while the affective aspect is less attention, so the development of moral values education as mandated in UU.No.20 about Sisdiknas in 2003 cannot be applied properly.

Through the moral value development model in science learning in schools, it is expected to be a vehicle for learners to learn about themselves and the environment, as well as the prospects for further development in applying it in daily life (KTSP SD, 2006: 484). Means the target to be achieved in science lesson, not limited to the concept alone, but other aspects are also very necessary, such as; independent, responsible, caring environment, tolerance of fellow friends, clever grateful for the favors provided, as well as aspects of character and others. Science learning in elementary schools needs to be done wisely and elastic (not rigid), so as not to adversely affect the environment (KTSP, 2006), which also means integrated value factor needs to be developed through the delivery of concepts learned in schools.

Based on some previous descriptions, it can be emphasized that "The Model of Development of Moral Values in the Elevation of Natural Science in Elementary Schools" is very necessary because in accordance with the demand of Sisdiknas, UU.No.20 of 2003, which is illustrated in the objectives of National Education, namely: learners to be human beings who believe and cautious to God Almighty, have a noble character, healthy, knowledgeable, capable, creative, independent, and become citizens of a democratic and responsible.

\section{METHOD}

This research uses literature study method. The literature used in this study consists of books, scientific journals, and websites related to the development of science learning model based on moral value. Reference theory used to be the main basis for research conducted. 


\section{DISCUSSIONS}

\section{Definition of Value Education}

Literally, "value is the price; size; numbers representing achievements; important traits that are useful to humans in living their lives (Ali, MB, 1997: 413). While according to that value is a belief about how to behave and the end goal desired by the individual, and used as a principle or standard in his life (Sauri, S, 2008: 28). Judging from the fundamental implications of daily life, Sauri (2008: 36), found that the value is functioning or useful for humans, as follows:

1. Guiding individuals in taking certain positions on certain social issues.

2. Influencing individuals to prefer certain political ideologies rather than other ideologies.

3. Directs how to present yourself to others.

4. Evaluate and make decisions.

5. Directing the appearance of the behavior of persuading and influencing others, informing individuals of the different beliefs, attitudes, values, and behavior of other individuals, who can be denied and denied, can be influenced and changed.

Those values when applied in a program, for example in the making of an educational curriculum, according to Phenix (1964) proposed by Mulyana (2004), should be designed with consideration of the sources of life meaningfully. In this way, the educational curriculum can last a long time and have essentials.

Education as a driver of human life towards the achievement of a goal, while the value as a praise or boundary or can also target, the benchmark is the values that come from the culture of society, or values derived from divine revelation, God the Supreme again Maha Compassionate, but when linked between two words, namely value and education, into educational value, means the quality of education; and if turned into a value education, it means the development of values that have to do with religious values, such as civilized, ethnicity, manners, morality, manners, mutual understanding, responsibility, independent, clean, diligent, and so forth.

Based on the description, the implementation of moral values education through various subjects, among them Science Subjects in schools is our duty as a professional lecturer who is full of responsibility to the Nation and State, which is done in a plan to humanize human beings through the development of valueethical values, aesthetic values, moral values, social values, economic values, and divine values in some of the lessons included in science teaching in schools.

\section{Characteristics of Science Learning in School}

Science is the result of human activities in the form of organized knowledge, ideas and concepts about the natural surroundings, gained from experience through a series of scientific processes such as investigation, idea-making, testing through experiments, information search and other scientific activities.

In addition, science is also a scientific group that focuses on understanding the universe and its behavior. By looking at the science activities as a process, then in the process of science learning in elementary school, science learning more emphasis on the activity of more students. This is in line with the demands of the 1994 curriculum, is that science is not just a series of facts, but is a process activity that must be done by humans such as gather information, interpret information, make conclusions about the results of a finding or finding a concept, and able to apply it in everyday and communicate it to others (Depdikbud, 1994: 15).

The expected goals in science learning are acquiring knowledge, improving skills and planting scientific attitudes and values. Science learning in schools not only requires students to remember factual information, but students are more directed to discovering, observing, experimenting, interpreting, summarizing, communicating and other support activities under the guidance of teachers implementing the lessons. 


\section{Learning Process of Science in Elementary School}

Learning process is a concept that contains elements of learning and teaching that cannot be separated from each other. Learning shows what a person should do as a subject receiving lessons, while teaching shows what a person should do as a teacher. These two elements, being integrated into an activity, occurs interaction between teacher and students during the learning takes place.

The learning process of science in elementary school, more emphasized the activity or the involvement of students in learning, the teacher as a facilitator only, then when this condition the teacher slowly, wisely, wisely implement "value education" to students, ultimately not forced to let alone depressed, students with pleasure psychologically accepting directions or suggestions from the teacher. This means that control is in the teacher. Therefore, before the learning is done there are some important things that must be prepared by the teacher, namely:

1. Teachers should make proper preparations in the form of RPP (Learning Implementation Plan), according to topics already programmed in Elementary School/Elementary School Science curriculum;

2. The focus or proper determination of the values to be developed in the learning through the making of Special Learning Objectives contained in the RPP;

3. Determining the appropriate use of appropriate approaches and methods, also programmed into RPP;

4. Determination of media use in the form of tools and materials in accordance with the objectives to be achieved at the end of the learning progress;

5. Learning structure should use SEQIP pattern, which always raises the problem at the beginning of instructional implementation by using the key questions.

6. At the end of the student's own learning which concludes the findings under the guidance of the teacher by incorporating the desired value concepts toward the goal to be achieved.

7. The teacher does the conceptual drafting before the final evaluation, damn giving homework as enrichment on the subject studied in school after the teacher doing final evaluation, and ending with the cover of prayer, as one implementation of gratitude value to God the Grace.

8. What teachers need to remember, any activity undertaken by the teacher from the beginning of learning to finish always inserted value messages to students so that the obtained knowledge students get the whole, complete and holistic.

9. Teachers must understand:

a. What is value education? Mastery of knowledge about value education that will be implemented in science teaching in schools, especially the values already described in National Education Goals (UU.No.20 Sisdiknas Year 2003).

How to implement moral values education in science learning in Elementary School /kindergarten including also in junior and senior high school and even though.

\section{CONCLUSIONS}

1. Science based learning model of moral values is an approach used by teachers in teaching science in schools (kindergarten, elementary/junior, junior and senior high school).

2. The objectives of teaching science to students, not only cognitive aspects, but affective aspects also need in addition to other aspects such as psychomotor, social, economical, full of responsibility, democratic, and others

3. To achieve that expectation, teachers need to approach and strategically appropriate and practical varied.

4. Evaluation as a reflective material to see the results, strengths/advantages, and disadvantages and solutions so that the next activity to get the learning results are maximal, whole, holistic and integrative. 


\section{REFERENCES}

Aswin, H.F. (1996). Psikologi Perkembangan Anak. Jakarta: Depdikbud.

Asy'ari, M. (1997). Pembelajaran Terpadu Antar Bidang Studi Sebagai Variasi Pengajaran di SD dengan Tema Sentral Bidang IPA. (Tesis). Bandung: PPS UPI Bandung.

Depdikbud. (1995). Kurikulum Pendidikan Dasar/ GBPP, Kelas V Sekolah Dasar Tahun 1994. Jakarta: Dirjen DIKTI.

Ertikanto, C. (1998). Pembelajaran Terpadu Model Integrated (Makalah). Bandung: PPS UPI Bandung.

Fogarty, R. (1991). How To Integrated The Curricule. Skylight Publishing, Inc. Palatine, Illinois. s

Hopkins, D. (1993). A Teacher's Guide to Classroom Research. Second Edition Buckingham, Philadelphia: Open University Press.

Joni, T.R. (1997). Pembelajaran Terpadu. Naskah untuk Pelatihan Guru Pamong SD, BP3GSD, DIKTI di Yogyakarta, Tanggal 4-16 Agustus 1997

Kartadinata, S dan Dantes. (1997). Landasan-Landasan Pendidikan Sekolah Dasar. Jakarta: Depdikbud.

Muhadjir, N. (1996). Pedoman Pelaksanaan Penelitian Pendidikan Kelas, Bagian Keempat: Analisis dan Refleksi. Yogyakarta: Dirjen DIKTI.

Peter, T. Schubeck, K, and Hopkins. (1995). A. Thematic Approach: Theory and Practice at the Aleknagik School. Phi Delta Kappan.76 (8).633-636.

Srini., M.I. (1997). Pendidikan Ilmu Pengetahuan Alam. Jakarta. BP3 GSD: Direktorat Jendral Pendidikan Tinggi (DIKTI).

Suyanto. (1997). Pedoman Penelitian Tindakan Kelas. Bagian Kesatu Yogyakarta: Direktorat Jendral Pendidikan Tinggi (DIKTI).

Tim Pengembang PGSD. (1997). Pembelajaran Terpadu D-II PGSD dan S 2 Pendidikan Dasar. Jakarta: Direktorat Jendral Pendidikan Tinggi (DIKTI). 